ArIstas, ensayos, por Antonio $S$. Pedreira.

Un catedrático de filosofía y letras de la Universidad de Puerto Rico, don Antonio S. Pedreira, es autor de este libro (1). En este caso la profesión del autor tiene mucha importancia. Hay, en efecto, varios trabajos de este volumen que no se explican sino como tareas propias del catedrático que debe metodizar sus conocimientos, reducirlos a esquemas claros e inteligibles, antes de darlos a conocer a sus oyentes o alumnos. Desde este punto de vista, algunos de los capítulos de Aristas pueden parecer excesivamente pedagógicos y hasta un poco limitados. Tal es el caso, por ejemplo, de ¿La generación del 98? y Los amores de Don Quijote y de algunos de los breves artículos agrupados bajo el título común de Lemas fugaces, hacia el fin del libro. Nos encontramos aquí evidentemente entre breves tesis o conferencias aptas para la cátedra de literatura. En ellos se insiste, a veces hasta la exageración, en ideas $y$ hecho's literarios sobradamente conocidos $y$ hasta vulgarizados ya en la prensa (periódica o no) de Hispano América en los últimos años.

Pero el resto del libro se compone de fragmento's dignos de la lectura más atenta. En el Ensayo cromático el autor intenta, por ejemplo, una biografía del color azul en la literatura. Es un tema nuevo y muy incitante. No cabe negar que el azul

(1) M. Aguilar, Editor. Madrid, 1930 . ha tenido un gran papel en las letras modernas, y que hasta en nuestros días ha sido perseguido por poetas y escritores. Es cierto que últimamente el negro-como raza $y$ como color - ha venido a ocupar ese lugar, como oportunamente nota el autor, tan bien informado de las letras más recientes como de los de data más antigua. Pero el autor hace arrancar la preeminencia del azul en el arte literario del Romanticismo (pág. 53). Esto me parece a mí equivocado. El Romanticismo gusta más de los tonos sombríos, que con frecuencia no designa específicamente sino en forma general, que del azul. Es cierto que el azul parece consustancial a la civilización occidental, como ha notado Spengler en su obra famosa. Mas el predominio efectivo del azul comienza más tarde y seguramente mucho después del triunfo y hasta de la muerte del Romanticismo. El tema, que entra claramente en la Literatura Comparada y que podría ser ampliado hasta límites mucho más amplios que las páginas de un ensayo, es, como se ve, incitante. Cada época tiene su color, y de acuerdo con los análisis que se han hecho de las obras de diversos escritores españoles representativos, hay gamas cromáticas que podrían ser estu: diadas con tanto detenimiento como las de los pintores en sus cuadros. (A este propósito conviene recordar el estudio de Dámaso Alonso sobre los colóres dominantes en Góngora (edición del Centenario), que el señor Pedreira no cita y que ciertamente no merece la omisión. 
Así como me he detenido en este ensayo sobre el color azul en la literatura, podría detenerme, y seguramente con mayor amplitud, en el trabajo titulabdo En torno a Henrik Ibsen. El gran dramaturgo del norte no es un tema virgen, y por el contrario, la bibliografía producida por sus obras es inmensa. El señor Pedreira ha sabido, sin embargo, acotar algunos aspectos nada comunes de la crítica en torno a Ibsen, y sus sugestiones abren camino a muchas observaciones curiosas.

Dos ensayos titulados De los nombres de Puerto Rico y ¿Portorriqueño o puertorriqueño? señalan la preocupación patriótica del autor por la tierra en que vive. No son los menos interesantes del volumen. En ambos el señor Pedreira se muestra copiosamente documentado $\mathrm{y}$ lo que es más importante- muy bien dotado para la crítica histórica.

En suma, el libro del señor Pedreira muestra a un escritor de ideas, que une a la elegancia de la forma una documentación que no es común en escritor americano. $\mathrm{El}$ señor Pedreira cita en una página inicial de su libro unas bellas palabras de Ortega y Gasset. Permítame recordarle otras del mismo maestro español sobre el espíritu americano. El americano, viene a decir Ortega y Gasset en un texto que debo conformarme con citar de memoria, pues no lo tengo a la mano, es un hombre que ronda en torno a las cosas, que no se adentra en el meollo de ellas, que no las posee $\mathrm{y}$, por tanto, no puede arrancarles su secreto.
Creo que uno de los mejores elogios que se puede hacer al señor Pedreira es que su libro presente, que al parecer es el primero que da a la luz pública, revela que nos encontramos ante un hombre que escribe sólo sobre lo que domina bien. Ninguna de las aseveraciones que se hacen en esta obra, ninguno de sus asertos, ninguno de sus juicios, carece del apoyo indispensable en los hechos $\mathrm{y}$ en las ideas que se les relacionan. El autor manda en su materia literaria con un seguro e indiscutible imperio. De alli la legítima autoridad de su tono y de allí también la certeza con el lector recorre este libro. Libro pensado con detenimiento y madurado sin prisa; es decir, libro que permànecerá.- $R$. Silva Castro.

\section{RenContres, por Robert Sébastien y Wsevolod de Vogt.}

Este volumen (1) de poco más de doscientas páginas reune las Soirées Franco-Russes de los días 29 de Octubre, 26 de Noviembre y 18 de Diciembre de 1929 y de 28 de Enero de 1930. Su título indica el género de los trabajos aquí contenidos. Se trata de los diversos puntos de vista que pueden of recer sobre la literatura rusa los escritores franceses y sobre la francesa los rusos emigrados en París. Conferencias $y$ debates sobre cuatro temas igualmente incitantes: $L a$ inquietud en la literatura, estudiada

(1) Aux Cahiers de la Quinzaine. París, 1930. 